\title{
Psödohipoparatiroidi Tip 2: Olgu Sunumu
}

\section{Pseudohypoparathyroidism Type 2: Case Report}

\author{
(iD Özlem Güleç Şen', (iDEmre Kaçar², (iD Tolga Altuğ Şen³.
}

${ }^{1}$ Afyon Sağlık Bilimleri Üniversitesi Tıp Fakültesi Kalp-Damar Cerrahisi Anabilim Dalı

${ }^{2}$ Afyon Sağlık Bilimleri Üniversitesi Tıp Fakültesi Radyoloji Anabilim Dalı

${ }^{3}$ Afyon Sağlık Bilimleri Üniversitesi Tıp Fakültesi Çocuk Sağlı̆̆ı-Hastalıkları Anabilim Dalı

$\ddot{O} z$

Psödohipoparatiroidi, parathormona karşı hedef organ düzeyinde cevapsızlık nedeniyle hipokalsemi ve hiperfosfatemi gelişmesiyle karakterize bir bozukluktur. Oldukça az görülen bu durumun iki tipi vardır, Tip 1 üç alt gruba ayrılmıştır. Psödohipoparatiroidi Tip 1A, diğer adıyla Albright'in herediter osteodistrofisi klinikte karakteristik yuvarlak yüz görünümü, frontal bombelik, kısa boy, obezite, brakidaktili ve mental retardasyonu olan hastalarda kolaylıkla tanınabilirken, Tip 1B ve Tip 1C'de normal fenotipik özellikler ve normal zeka vardır. Tip 1'de paratiroid direnci ile birlikte TSH ve gonadotropin direnci de tanımlanmış hastalar bulunmakta iken, Tip 2'de sadece paratiroid hormon direnci tanımlanmıștır. Ellerde, ayaklarda kasılma şikayeti ile Kalp-Damar Cerrahisi polikliniğine başvuran 12 yaşındaki kız hastaya psödohipoparatiroidi Tip 2 tanısı koyarak kalsiyum ve D vitamini ile başarılı bir şekilde tedavi ettik. Psödohipoparatiroidi Tip 2'nin nadir gözlenen bir durum olması nedeniyle de olgu sunumu yaptık.

Anahtar Kelimeler: Hipokalsemi, hiperfosfatemi, hiperparatiroidi.

\begin{abstract}
Pseudohypoparathyroidism is a disorder characterized by hypocalcemia and hyperphosphatemia due to unresponsiveness of target organs to the parathormone. In this quite rare condition two types of disease exists and type 1 have 3 subtypes. Pseudohypoparathyroidism type $1 \mathrm{~A}$ is known as Albright's hereditary osteodystrophy, is clinically recognizable in patients with characteristic round face, frontal camber, short stature, obesity, brachydactyly and mental retardation, in type 1B and in type 1C, normal phenotypic features and normal intelligence were present. With parathyroid hormone resistance, TSH and gonadotropin resistance has also been identified simultaneously in type 1 patients, while in type 2 patients only parathyroid hormone resistance has been defined. Because of it was a very rare condition, we present a twelve years old girl patient admitted to Cardiovascular Surgery outpatient polyclinic with the complaint of spasm in hands and feet, diagnosed as pseudohypoparathyroidism type 2 who was treated successfully by calcium, vitamin D.
\end{abstract}

Keywords: Hypocalcemia, hyperphosphatemia, hyperparathyroidy.

\section{Giriş}

Paratiroid hormona (PTH) hedef organ yanıtsızlığı Albright ve ark. (1) tarafından tanımlanmış ve psödohipoparatiroidi (PHP) olarak adlandırılmıştır. Psödohipoparatiroidi (PHP) otozomal dominant geçişli bir genetik bozukluktur, prevalansı kesin bilinmemekle birlikte milyonda 3.4 olduğu tahmin edilmektedir (2). Doku düzeyinde yanıtsızlığa sekonder olmak üzere PTH düzeyi yüksektir, ancak biyokimyasal olarak PTH eksikliği durumuna benzer şekilde hipokalsemi, hiperfosfatemi gözlenir. PHP'nin Tip-1A, Tip-1 B, Tip-1 C ve Tip-2 olmak üzere tipleri vardır, Tip 1A Albright'ın herediter osteodistrofisi (AHO) olarak adlandırılır (3). Albright'ın herediter osteodistrofisi (AHO)'nin karakteristik klinik özellikleri vardır; yuvarlak yüz, frontal bombelik, kısa boy, obezite, brakidaktili, kısa ulna, kubitis valgus, genu varum, genu valgum gözlenebilir, olguların yaklaşık yarısı mental retardedir. Tip 1 PHP'de PTH ile birlikte büyüme hormonu, tiroid stimulan hormon (TSH), GnRH (Gonadotropin Releasing Hormon)'a direnç varken, Tip 2 PHP'de sadece PTH'a direnç vardır. Hastalarda hipokalsemi ile ilişkili olarak nöbetler, karpopedal spazm, kramplar, parestezi, bazal ganglionlarda kalsifikasyonlar ve katarakt görülebilir $(4,5)$.

Burada hipokalsemiye sekonder el ve ayaklarda uyuşma, kasılması olan, belirgin fenotipik özellikleri olmayan, ancak hem doku düzeyinde PTH direncine, hem de D vitamini eksikliğine sekonder PTH yüksekliği saptanan 12 yaşında kız olgu sunulmaktadır. Önemli düzeyde hipokalsemisi ve hiperfosfatemisi olan, normal fenotipik özellikleri ve normal zekası olan ve sadece paratiroid hormon direnci olması ile Tip 2 ile uyum gösteren 12 yaşındaki kız olgu, kalsiyum ve D vitamini ile tedavi edilmiş, başarılı bir şekilde klinik ve biyokimyasal düzelme sağlanmıştır.

Yazıșma Adresi: Özlem Güleç Șen, Afyon Sağlık Bilimleri Üniversitesi Tıp Fakültesi, Kalp ve Damar Cerrahisi

E-Posta: tolgasen69@yahoo.com

Alınma Tarihi: 29.03.2019 / Kabul Tarihi: 09.05.2021 / Yayımlanma Tarihi: 15.06.2021 


\section{Olgu Sunumu}

Oniki yaşında kız olgu, son 1 aydır her iki elde ve ayak parmaklarında kasılma ve uyuşma şikâyetleri ile başvurduğu Kalp-Damar Cerrahisi polikliniğinde yapılan tetkiklerinde kalsiyum düşük, fosfor yüksek bulunması nedeniyle Çocuk Sağlığı ve Hastalıkları polikliniğimize yönlendirildi.

Özgeçmişinde ve soygeçmişinde özellik bulunmayan olgunun fizik muayenede boy: $165 \mathrm{~cm}$ (97p), vücut ağırlığı: $62 \mathrm{~kg}$ (97p), vücut kitle indeksi $22.5 \mathrm{~kg} / \mathrm{m} 2$, yuvarlak yüzlü ve normal zekada idi (Resim 1). Alt ve üst ekstermitelerde deformite yoktu (Resim 2-3). Bilateral el ve ayak kaslarında kasılmalar, tetani mevcuttu. Olgunun nabiz:80/ dk, TA: 110/80 mmHg idi. Chvostek ve Trousseau belirtileri müspet bulundu. Telarş ve pubarş Tanner evre 3 olarak tespit edildi, henüz menslerin başlamadığ 1 ögrenildi. Nörolojik muayenede olgunun serebellar testleri doğal, derin tendon refleksleri alt ve üst ekstremitede azalmış, patolojik refleks yoktu. Fundoskopide göz dibi incelemesi olağan bulundu. Bakılan Ca düzeyinin $5.6 \mathrm{mg} / \mathrm{dl}(\mathrm{N}: 8,4-10,2 \mathrm{mg} /$ dl), P: 11,15 mg/dl (N:2,5-4,5 mg/dl), ALP: $355 \mathrm{U} / \mathrm{L}$, Albumin:3,6 $\mathrm{mg} / \mathrm{dl}(\mathrm{N}: 3,5-5 \mathrm{gr} / \mathrm{dl})$, düzeltimiş Ca düzeyi $6.0 \mathrm{mg} / \mathrm{dl}$, serum iyonize kalsiyum düzeyi $0,6 \mathrm{mmol} / \mathrm{L}(\mathrm{N}: 1,12-1,30 \mathrm{mmol} / \mathrm{L})$, magnezyum 1,8 $\mathrm{mg} / \mathrm{dl}(\mathrm{N}: 1,6-2,6 \mathrm{mg} / \mathrm{dl})$. PTH $457 \mathrm{pg} / \mathrm{ml}$ ( 15-65 pg/ml), 25-OH vit D $15.69 \mathrm{ng} / \mathrm{ml}(10-50 \mathrm{ng} / \mathrm{ml})$, TSH $2.15 \mathrm{uIU} / \mathrm{ml}(0.27-4.2 \mathrm{uIU} / \mathrm{ml})$, fT4 $1.18 \mathrm{ng} / \mathrm{dl}(0.93-1.7 \mathrm{ng} / \mathrm{dl}), \mathrm{LH}: 3.41 \mathrm{mIU} / \mathrm{ml}$ (N:2-12 mIU/ml), FSH: $5.83 \mathrm{mIU} / \mathrm{ml}(\mathrm{N}: 3,5-12,5 \mathrm{mIU} / \mathrm{ml})$. Çölyak hastalığ için bakılan testler negatif, EKG'de QT aralığı normal sinırlarda bulundu.

El grafilerinde ve ayak grafilerinde metakarpal veya metatarsal kemik kısalığı yoktu (Resim 4-5). Boyun USG'sinde lenfadenopati mevcut değildi, tiroid parenkimi ve boyutları normal bulundu (paratiroid bezi ile ilgili inceleme için suboptimal idi). Kranial BT'de subkortikal alanlarda, her iki internal kapsül genusu ve anterior bacağında, her iki kaudat nukleus lokalizasyonuda lineer kalsifikasyonlar mevcuttu (Resim 6-7). Kraniyal MRI'da bilateral kaudat nukleus düzeyinde flair intensiteler mevcuttu (Resim 8-9).

Çocuk Sağlığı-Hastalıkları servisinde takibe alınan hastaya hipokalsemiye bağlı kasılmaları mevcut olan hastaya parenteral 2 ampul \%10 kalsiyum glukonat $\% 5$ dekstroz içerisinde infüzyon olarak verildi ve kalsitriol $0.5 \mathrm{mcg} 2 \times 1$ tablet başland. Serum $25(\mathrm{OH}) \mathrm{D}$ vitamini düşüklügüü sebebiyle oral tek doz 300.000 Ünite D vitamini takviyesi yapıldı. Tedavinin ilk gününde el ve ayaklardaki kasılmanın geçtiği, 3. gününden itibaren Chvostek ve Trousseau bulgularının kaybolduğu gözlendi. Klinik iyileşme sağlanan hastaya $1000 \mathrm{mg}$ kalsiyum $+880 \mathrm{IU}$ vitamin D3 effervesan tablet $2 \times 1$, kalsitriol $0.5 \mathrm{mcg}$ kapsül 2x1 verildi, tedavinin 5. gününde bakılan düzeltilmiş kalsiyum düzeyi 7,7 mg/dl'ye yükseldi, fosfor $6,5 \mathrm{mg} / \mathrm{dl}$ 'ye gerileyen olgu oral tedavisi düzenlenerek ayaktan izlenmek üzere taburcu edildi.

\section{Tartıșma}

Parathormonun yetersiz salınımında hipoparatiroidi gelişirken, serum PTH hormon, kalsiyum düzeyi düşük, buna karşın fosfat düzeyi yüksektir. Psödohipoparatiroidide (PHP) ise kalsiyum düzeyi düşük ve fosfat düzeyi yüksek iken PTH hormon düzeyi, vücut PTH'a yeterli yanıt vermediğinden başka bir deyişle hedef organ direnci olduğundan dolayı yüksektir. Parathormon, D vitamini eksikliğine bağlı olarak yükselir, buna sekonder hiperparatiroidi denir, bu durumda hipokalsemi ile birlikte fosfor düzeyi düşük veya normalin alt sınırındadır $(4,5)$. Olgumuzda 25(OH)D vitamini takviyesi sonrası PTH düzeyinin azaldığı gözlenmiştir. Bu durum bizim olgumuzda PTH yüksekliği hem hedef organ resistansına bağlı hem de D vitamini eksikliğine bağl1 olarak oldukça yüksek bulunmuş olabileceğini düşündürmüştür. Ciddi magnezyum eksikliği paratiroid bezde geçici paralizi yaparak, hormon salınımını durdurabilir $(4,5)$. Magnezyum eksikliği ayrıca PTH'nin böbrek ve kemik dokular gibi hedef dokularında etkisini azaltmakta, bu durum magnezyum infüzyonu ile kısa sürede geri dönebilmektedir. İleri derecede D vitamini eksikliğinde PTH artarken, serum magnezyum düzeyleri azalmakta, olgumuzun magnezyum düzeyleri normal sınırlarda olması hafif $\mathrm{D}$ vitamini eksikliği olması nedeniyledir. Serum D vitamini düzeyinin yeterli sayılması için, $50 \mathrm{ng} / \mathrm{ml}$ 'nin üzerinde olmalıdır (5). Olgumuzun serum 25(OH) D vitamini düzeyinin $12.5 \mathrm{ng} / \mathrm{ml}$ 'nin altında olması Lawson Wilkins Pediatrik Endokrin Topluluğunun 2008 yılında yayınladığı derleme sonuçlarına göre "şiddetli D vitamini eksikliği" düzeyine oldukça yakın bulunmuştur (6). Şiddetli D vitamini eksiklik düzeyine yakın D vitamini olması nedeniyle olgumuza oral tek doz 300.000 ünite D vitamini verilerek serum D vitamini düzeyi $50 \mathrm{ng} / \mathrm{ml}$ 'nin üzerine çıkarılmıştır. Hipokalsemi ile birlikte hiperfosfatemi ve yüksek PTH tespit edilen olguda öncelikle PHP düşünülmeli, karakteristik fenotipik görünümü ve mental retardasyonu olan hastalara PHP tip 1A tanıs1 konulurken, bu özellikler tespit edilmeyen olgularda diğer PHP tipleri tanısı konulmalıdır. Psödohipoparatiroidinin her üç tipinde G-protein geninin (GNAS1 gen) mutasyonları saptanmıştır. Tip-1A, PHP'li hastaların yaklaşık 50'sini oluşturur, Tip-1A'da G-protein aktivitesi düşüktür, bu düşüklük sebebiyle adenil siklaz sitemiyle çalışan TSH, LH, FSH ve glukagon gibi hormonlara da direnç gelişimi söz konusu olabilir (7). Olgumuzda TSH, FSH, LH hormonlarına direnç yoktu. Olgumuzda sadece parathormon direnci olması, fenotip ve zekaca normal olması tip 2 ile uyumlu olduğunu düşündürdü.

Parathormon direncini göstermek için tanısal amaçlı olarak Ellsworth-Howard testi sentetik human PTH kullanılarak yapılır. Bu amaçla teriparatide acetate $3 \mathrm{IU} / \mathrm{kg} 10$ dakika üzerinde infuze edilir ve sonrasındaki idrar toplanılır, infuzyondan sonraki ilk 30 dakika, 30-60 dakika ve bazen 1-2 saatler arası idrar toplanarak cAMP, fosfat ve kreatinin çalış1lır. Ellsworth-Howard testi ile PHP'de sentetik PTH uygulaması sonrası idrarda beklenen cAMP artışı olmaz (8). Sentetik parathormon (Teriparatide acetate) temin edilemediği ve edilse bile kliniğimizde idrarda cAMP düzeyi bakılamadığı için olgumuza bu test yapılamadi.

Parathormona tarafından kontrol edilen ileti sistemi, reseptör, adenil siklaz ve G-protein olmak üzere üç kısımdan oluşur. Burada G-proteini, PTH'yi hücre duvarındak reseptörlere bağlayarak cAMP'yi aktive etmektir. Hastalığın tüm formlarında G-protein geninin (GNAS1 gen) mutasyonları saptanmıştır. Tip-1 A'da G-protein aktivitesi düşüktür. G-protein aktivitesinin eksikliği generalize hücresel bir bozukluk oluşturmaktadır, bu eksiklik adenil siklaz sistemiyle çalışan TSH, LH, FSH ve glukagon gibi hormonlara direnç gelişimine yol açmaktadır. Tip-1B PHP'de G- protein aktivitesi ve fenotipi normal olup hedef dokularda PTH'ye direnç varken diğer hormonlara direnç yoktur (9). Tip 1B'nin Tip 1A'dan ayırdedici özellikleri ise AHO somatik özelliklerinin olmaması, kemik yanıtının olması nedeniyle alkalen fosfatazın yüksek bulunmasıdır (11). Tip1B, 1C ve Tip2'de PHP'de G- protein aktivitesi düşük değildir ve olgular fenotip olarak normaldirler, hedef dokularda PTH dışındaki hormonlara direnç yoktur (12). PHP'de beyinde genellikle bazal ganglionlarda kalsifikasyonlar gözlenebilmekte; ayrıca subkutan dokuda, kalpte kalsifikasyonlar görülebildiği bilinmektedir (12). Olgumuzun hem kranial BT'de hem kraniyal MRI'da kalsifikasyonlar mevcut olması tanıyı destekleyen bir başka bulgu olarak tespit edildi (Resim 6-9). Kalsifikasyonlar çoğunlukla simetrik olarak dentat 
çekirdek, bazal gangliyon, talamus ve sentrum semiovalede görülür (13). Hipokalseminin süresi uzadıkça, intrakraniyal kalsifikasyonlara rastlanma sıklığ 1 artar, intrakraniyal kalsifikasyonun mekanizması ise bilinmemektedir. Beyin dokusunda kalsiyum birikimini göstermek için en sık kullanılan inceleme yöntemi beyin BT'dir, beyin MR'ın semptomatik vakaların belirlenmesinde ve etiyolojilerinde daha üstün olduğunu bildiren çalışmalar da vardır (14).

Hiperfosfatemi ile birlikte Albright'n osteodistrofi bulguları görüldüğünde PHP tanısı kolaylıkla konulabilir. El ve ayaklarda hipokalsemiye bağlı kasılma ile gelen olgunun, 25(OH) D vitamini düşüklüğüne bağlı yüksek PTH olsa idi, hipofosfatemi veya normofosfatemi olması beklenirdi.

Sonuç olarak düşük serum kalsiyumu ile birlikte hiperfosfatemi ve yüksek PTH tespit edilen olguda öncelikle PHP düşünülmeli, karakteristik fenotipik görünümü, mental retardasyonu olan hastalarda ise PHP tip 1A olmayanlara ise PHP tip 2 tanısı konulmalıdır. Parenteral kalsiyum ile klinik düzelme sağlanma sonrasında oral yoldan $\mathrm{Ca}$ ve aktif $\mathrm{D}$ vitamini replasmanı tedavisi ömür boyu verilmesi gerekmektedir. Tedavi amacı normokalsemiye yakın değerleri sağlarken, hastaları metastatik kalsifikasyonlardan korumak olmalıdır. Hastaların çoğunluğunun bu seviyelerde asemptomatik olması nedeniyle tedavi ile birlikte hedef kalsiyum seviyesi normalin alt sınırında, 8-8.5 mg/dl civarında hedeflenmesi önerilmektedir. Bu değerlerin üzerindeki kalsiyum seviyeleri hiperkalsiüriye, uzun süren hiperkalsiüri nefrokalsinozise veya nefrolitiyazisa neden olabilir.

\section{Kaynaklar}

1. Albright F, Burnett CH, Smith PH. Pseudohypoparathyroidism: an example of "Seabirght- Bantam syndrome." Endocrinology 1942; 30: 922-32.

2. Nakamura Y, Matsumoto T, Tamakoshi A, Kawamura T, Seino Y, Kasuga M, Yanagawa H, Ohno Y. Prevalence of idiopathic hypoparathyroidism and pseudohypoparathyroidism in Japan. J Epidemiol 2000; 10: 29-33.

3. Gardner DG, Shoback D. Greenspan s Basic \& Clinical Endocrinology. Lange 9th edition. Mc graw Hill, 2011, 254-56.

4. Bringhurst FR, Demay MB, Kronenberg HM: Hormones and disorders of mineral metabolism. In: Williams Textbook of Endocrinology. 9th ed. WB Saunders Company, 1998: 1155- 1209.

5. Hatun Ş, Bereket A, Çalıkoğlu AS, Özkan B: Günümüzde D vitamini yetersizliği ve nutrisyonel rikets. Çocuk Sağ. ve Hast. Dergisi, 2003; 46:224-41.

6. Misra M, Pacaud D, Petryk A, Collett-Solberg PF, Kappy M; Drug and Therapeutics Committee of the Lawson Wilkins Pediatric Endocrine Society. Vitamin D deficiency in children and its management: review of current knowledge and recommendations. Pediatrics. 2008; 122: 398-417.

7. Davies SJ, Hughes HE: Imprinting in Albright's hereditary osteodystrophy. J Med Genet, 1993; 30: 101-3

8. Levine MA: Hypoparathyroidism and pseudohypoparathyroidism. In: DeGroot, Jameson, et al eds. Endocrinology. 4th ed. WB Saunders Company; 2001: 1133-53.

9. Maeda SS, Fortes EM, Oliveira UM, Borba VC, Lazaretti-Castro M. Hypoparathyroidism and pseudohypoparathyroidism. Arq Bras. Endocrinol Metabol 2006; 50: 664-73.

11. Kidd GS, Schaaf M, Adler RA, Lassman MN, Wray HL. Skeletal responsiveness in pseudohypoparathyroidsim. A spectrum of clinical disease. Am J Med 1980; 68: 772-81.

12. Levine MA. Clinical Review: Pseudohypoparathyroidism: From bedside to bench and back. J Bone Miner Res 1999; 14: 1255-60.

13. Windeck R, Menken U. Basal ganglia calcification in pseudohypoparathyroidism typeII. Clin Endocrinol 1981; 15: 57-63.

14. Scotti G, Scialfa G. MR imaging in Fahr disease J Comp Assist Tomog 1985; 9(4):790-2. 
Resim 1
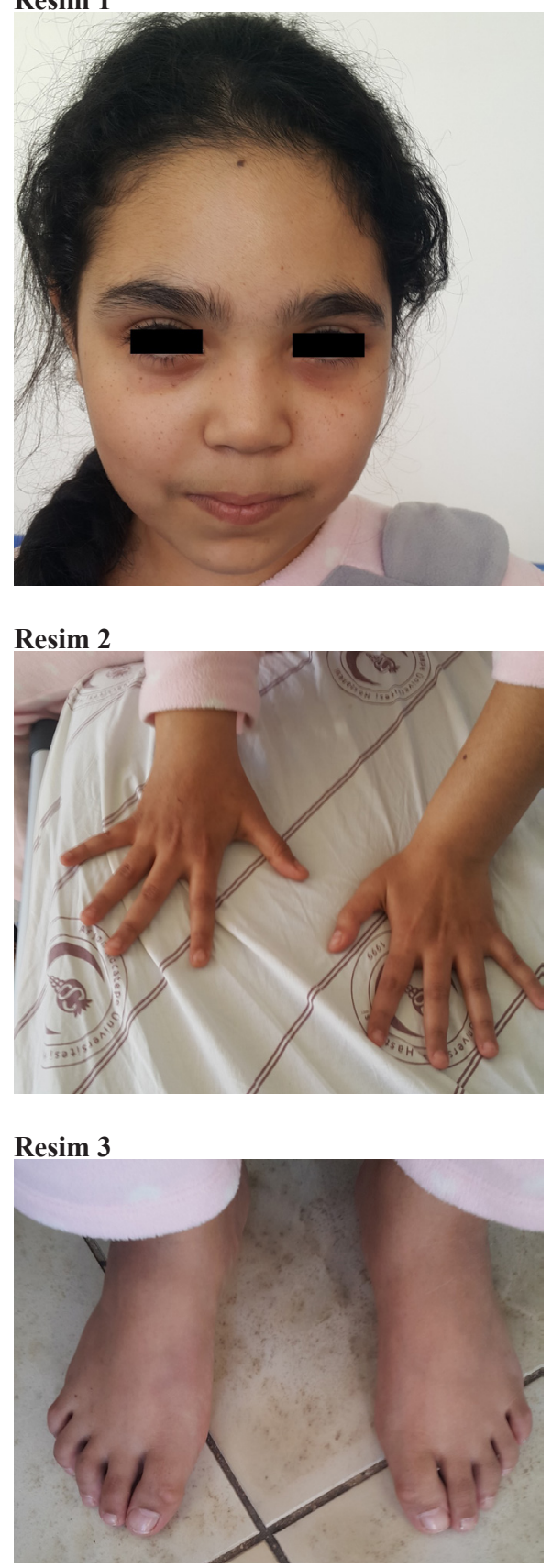

Resim 4

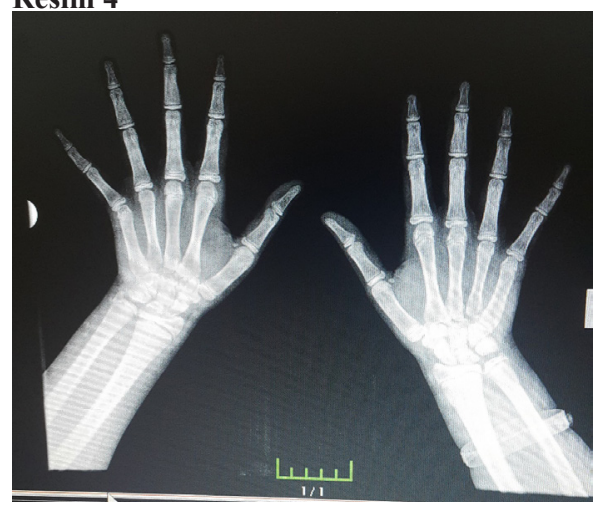

\section{Resim 5}

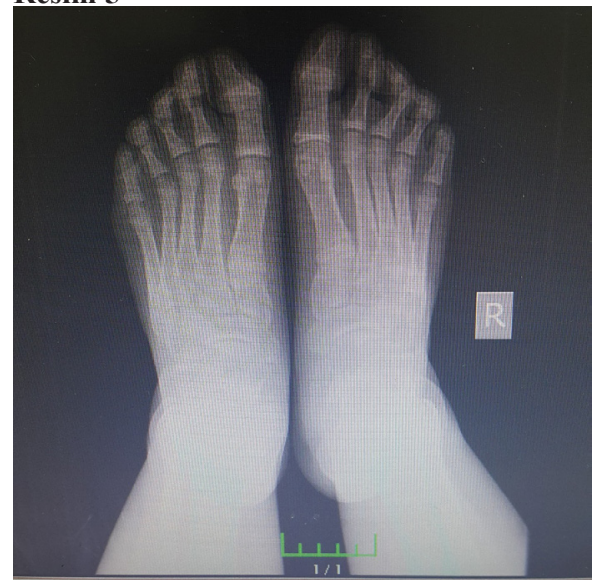

Resim 6

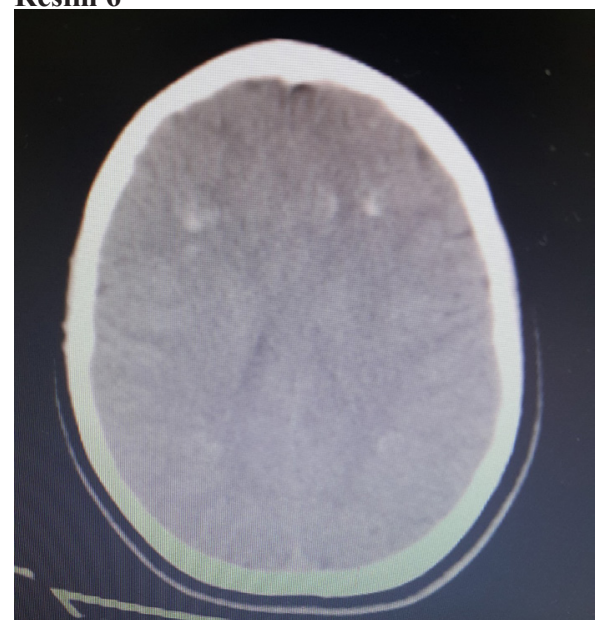

Resim 7

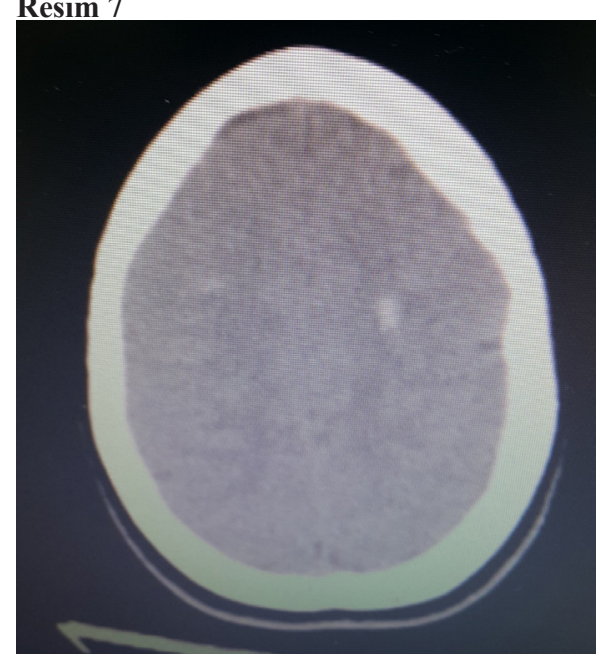

Resim 8

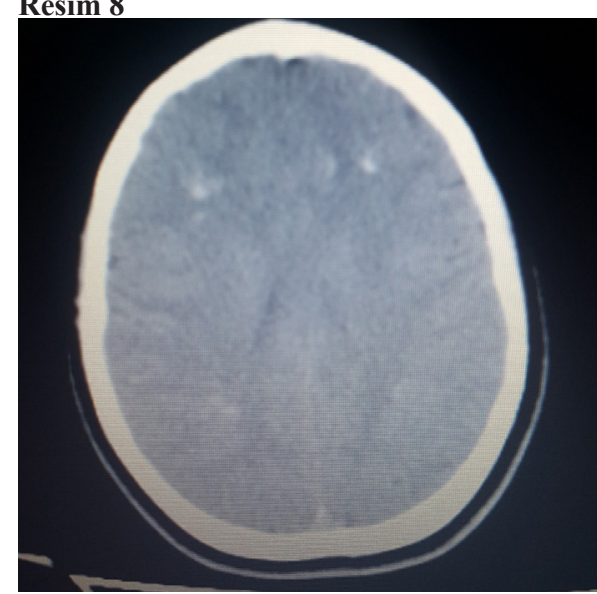

Resim 9

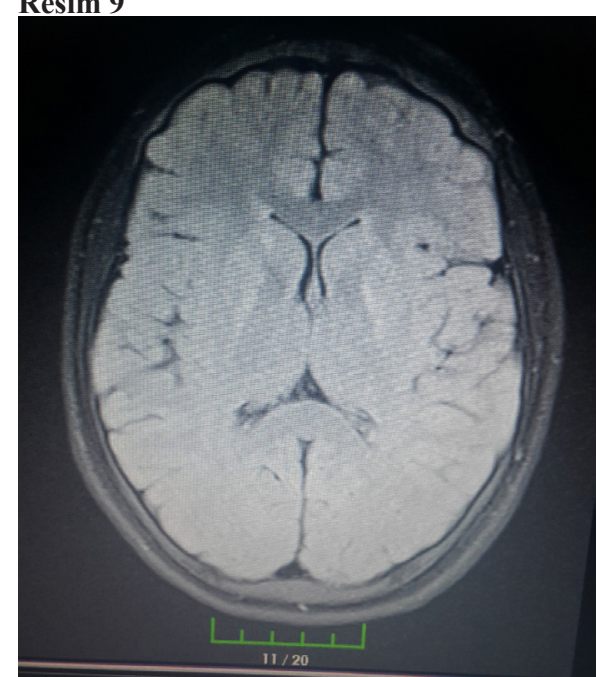

